\title{
Models for government-nonprofits partnerships: a comparative analysis of policies for AIDS, social assistance and culture in Brazil
}

\author{
Patrícia Maria Emerenciano de Mendonça ${ }^{1}$ \\ Anny Karine de Medeiros ${ }^{2}$ \\ Edgilson Tavares de Araújo ${ }^{34}$ \\ 1 Universidade de São Paulo / Escola de Artes Ciências e Humanidades, São Paulo / SP - Brazil \\ 2 Fundação Getulio Vargas / Escola de Administração de Empresas de São Paulo, São Paulo / SP - Brazil \\ 3 Universidade de Brasília / Centro de Estudos Avançados Multidisciplinares, Programa de Pós-Graduação em Desenvolvimento, \\ Sociedade e Cooperação Internacional, Brasília / DF - Brazil \\ ${ }^{4}$ Universidade Federal da Bahia, Salvador / BA - Brazil
}

This study contributes to the research on partnership models by comparing different policy areas, testing the existing typologies and developing new forms of analysis for the Brazilian context. The literature on partnerships regarding the nonprofit sector is focused on the great diversity of these organizations and the types of relationship they establish with the government to provide services. Most empirical studies on this issue seek to establish categories for the partnerships analyzed, usually comparing countries or policy areas on a macro level. This study observes how partnership models help to understand the differences among policy areas, observing cases in the areas of AIDS, social assistance, and culture in Brazil. The research introduced field level variables and organizational variables to establish clearer differences among the models, and to identify where they overlap. Differences among the models helped to test relational variables and use the partnership models to analyze the public policy areas on the interaction design with nonprofits. As for political implications, this study provides recommendations to advance in a governmental agenda on partnerships that can combine general guidelines with particularities related to each policy area. Finally, the study indicates that partnerships should be considered public policy instruments.

Keywords: nonprofit organizations; partnerships; social policies; collaboration.

\section{Modelos para parcerias entre governos e organizações da sociedade civil: análise comparativa de políticas de AIDS, assistência social e cultura no Brasil}

Este estudo contribui para a pesquisa sobre modelos de parceria, comparando diferentes áreas de política, testando as tipologias existentes e desenvolvendo novas formas de análise para o contexto brasileiro. A literatura sobre parcerias em relação ao setor sem fins lucrativos está focada na grande diversidade dessas organizações e nos tipos de relacionamento que estabelecem com o governo para a prestação de serviços. A maioria dos estudos empíricos sobre essa questão busca estabelecer categorias para as parcerias analisadas, geralmente comparando países ou áreas de políticas em um nível macro. Este estudo observa como os modelos de parceria ajudam a entender as diferenças entre áreas de políticas públicas, observando casos nas áreas de AIDS, assistência social e cultura no Brasil. A pesquisa introduziu variáveis de nível de campo e variáveis organizacionais para estabelecer diferenças mais explícitas entre os modelos e para identificar onde elas se sobrepõem. As diferenças entre os modelos ajudaram a testar as variáveis relacionais e usar os modelos de parceria para analisar as áreas de política pública no desenho de sua interação com as organizações. Quanto às implicações políticas deste estudo, ele fornece recomendações para avançar em uma agenda governamental sobre parcerias que podem combinar diretrizes gerais com particularidades relacionadas a cada área. Por fim, o estudo indica que as parcerias devem ser consideradas como instrumentos de política pública.

Palavras-chave: entidades sem fins lucrativos; parceiras; políticas sociais; colaboração. 


\section{Modelos para alianzas entre gobiernos y organizaciones de la sociedad civil: análisis comparativo de políticas de SIDA, asistencia social y cultura en Brasil}

Este estudio contribuye a la investigación sobre modelos de alianzas al comparar diferentes áreas de políticas, probar las tipologías existentes y desarrollar nuevas formas de análisis para el contexto brasileño. La literatura sobre alianzas en relación con al sector de entidades sin fines de lucro se centra en la gran diversidad de estas instituciones y en los tipos de relación que establecen con el gobierno para brindar servicios. La mayoría de los estudios empíricos sobre este tema buscan establecer categorías para las alianzas analizadas, generalmente comparando países o áreas de políticas a nivel macro. Este estudio observa cómo los modelos de alianza ayudan a comprender las diferencias entre áreas de políticas públicas, observando casos en las áreas de SIDA, asistencia social y cultura en Brasil. La investigación introdujo variables de nivel de campo y variables organizativas para establecer diferencias más explícitas entre los modelos e identificar dónde se superponen. Las diferencias entre los modelos ayudaron a probar las variables relacionales y a usar los modelos de alianza para analizar las áreas de políticas públicas. En cuanto a las implicaciones políticas de este estudio, proporciona recomendaciones para avanzar en una agenda gubernamental sobre alianzas que pueden combinar directrices generales con particularidades relacionadas con cada área de política. Finalmente, el estudio indica que las alianzas deben considerarse como instrumentos de política pública.

Palabras clave: entidades sin fines de lucro; alianzas; políticas sociales; colaboración.

\section{INTRODUCTION}

Studies on government-nonprofit partnerships have been concentrated in European and North American contexts with few studies elsewhere. In Latin America, more research is needed to systematize these models (Appe \& Layton, 2016; Peci, Figale, \& Sobral, 2011). Academic debate on the topic in Brazil is scattered, focusing on issues such as: regulation and control, comparative advantages and limitations for each part in service providing, systematization of historical data on partnerships at the federal level, and engagement among professionals across sectors (Alves \& Koga, 2006; Campos, 2008; Campos, Mendonça, \& Alves, 2012; Lopez \& Abreu 2014; Lopez, Lopes, Souto, \& Sant’Ana, 2014; Peci et al., 2011; Resende \& Teodosio, 2014; Salinas, 2013).

Different types of partnership are established across policy areas. In order to create an analytical framework for partnerships, we must account for the nature of this object as a changing space of interactions, which combines different organizational logics (Brinkerhoff, 2002; Bode \& Brandsen, 2014).

This article aims to contribute to this research agenda by comparing different partnership models, testing the existing typologies, and developing new forms of analysis for the Brazilian context. Three policy areas, AIDS, social assistance and culture, were selected because they include partnerships in policy/program design, even though they vary in local implementation.

In this study, public policy is not understood as a synonym of policy instruments, even though there is a strong metonymy relationship between them (Boullosa, 2013). Partnerships are not public policies per se, but rather an instrument of public policies, that is, a technical and social device that organizes the specific social relations between the public power and its addressees in function of representations and of meanings of which it is a bearer (Lascoumes \& Le Galés, 2012).

This introduction is followed by a section detailing the methodology used. The theoretical review presented after the methodology shows the academic literature on models and typologies of partnerships, as well as it describes the categories and levels of analysis used. 
The fourth section provides a brief overview of the policies on AIDS, social assistance, and culture (which focus on the Cultura Viva program) with regards to government-nonprofits partnerships. The fifth section presents a systematization and analysis of the various models found. It discusses the findings based on the analytical model developed in the previous section.

Concluding remarks point to significant differences of models among policy areas, also confirming that models often overlap. However, they are still useful in capturing complexity and diversity of partnerships, identifying differences and similarities among areas, being good schemes for testing propositions across different contexts.

Future research focusing on this agenda must seek to combine qualitative and quantitative approaches with surveys about specific elements of the partnerships and features of nonprofits. As for policy implications based on the results found in partnerships analyzed in three policy areas in Brazil, suggestions are to advance the debate on the agenda of partnerships for the provision of public services emphasizing the importance of general guidelines and also specificities in each area.

\section{METHODOLOGY}

The analytical model developed on this study was based on the literature reviewed, using as a guideline the work of Doty and Glick (1994), who present important considerations to differentiate typologies, with the purpose of constructing theories and proposing hypotheses.

According to Doty and Glick (1994), typologies are good schemes to deal with diverse and complex contexts. They are more abstract constructions than just classifications, which must be the subject of rigorous empirical tests. They are composed of interrelated sets of ideal types, each representing a unique combination of attributes that are believed to influence outcomes. Our proposed analytical model, containing ideal types of partnership and their attributes are presented in detail in the next session.

In order to test this model and make suggestions for future developments, this research observed three different and representative cases of partnerships in the policy areas of AIDS, social assistance and culture. An analysis of multiple case studies was performed, considering that, as recommended by the literature, different cases may not be directly comparable, but it is possible to learn from analyzing them together (Stake, 1995).

The policy areas of AIDS and social assistance have a long history of engagement with nonprofits (Araújo, 2015a; Campos \& Mendonça, 2010). In the area of culture, the program analyzed (Cultura Viva) was created in 2004, and it was considered an innovation as a cultural policy and in the way it designed partnerships (Medeiros, 2013).

This study considered only the policy design, which occurs at the central government level, not analyzing the implementation at the local level. The analysis at the Federal level allows comparability, but limits the detailing options, since each policy/program might unfold differently in local implementation contexts. At the same time, policies and guidelines formulated at the Federal level, impact specifically on the nature of relationships in local implementation contexts, regardless of how heterogeneous and diverse they are.

As previously mentioned, partnerships are not public policies per se, but rather, public policies instrument. Thus, the partnership cases analyzed show complex policy design that combines different instruments of public policies for the supply of public goods and services. 
Time scope for the analysis of the three cases was limited from 2002-2015, which encompass the main period of welfare expansion (and expansion of partnerships with nonprofits) in Brazil, observing that most forms of service provision had some degree of participation of nonprofit organizations.

According to Eisenhardt (1989), theory-building approaches typically combine multiple data collection methods, such as the triangulation, which is a viable way to provide stronger substantiation of constructs and hypotheses (Eisenhardt, 1989). Following this lead, the data used in this research was collected through primary and secondary databases: literature review, and government documents. After a first systematization using secondary data, primary data were used to fill gaps and to triangulate results, achieved through interviews. We were able to conduct five in-depth interviews of focal managers, three at the Ministry of Health, one at Ministry of Social Development and one at the Ministry of Culture. In this sense, the study was based on extensive existing materials which were reorganized for its purposes, as shoed on Box 1.

\section{BOX 1 METHODS AND SOURCES TO DATA COLLECTION}

\begin{tabular}{|c|c|c|c|}
\hline Methods of data collection & AIDS & Social Assistance & Culture \\
\hline $\begin{array}{l}\text { Secondary data from previous } \\
\text { research projects and } \\
\text { publications }\end{array}$ & $\begin{array}{l}\text { Campos and Mendonça } \\
\text { (2010), Campos et al. } \\
\text { (2012), which used } \\
\text { qualitative approaches } \\
\text { based on interviews, } \\
\text { document analysis, and } \\
\text { in-depth case descriptions. }\end{array}$ & $\begin{array}{l}\text { Araújo (2015a, 2015b, } \\
2015 c) \text {, which } \\
\text { used qualitative research } \\
\text { focused on people with } \\
\text { disability, based on interviews, } \\
\text { focus group, and participatory } \\
\text { research. }\end{array}$ & $\begin{array}{l}\text { Medeiros (2013), } \\
\text { Medeiros, Alves, and } \\
\text { Farah (2015), which used } \\
\text { qualitative and quantitative } \\
\text { approaches based on } \\
\text { interviews, document } \\
\text { analysis, survey with } 31 \\
\text { Pontos de Cultura (cultural } \\
\text { centers) (Medeiros, 2013). }\end{array}$ \\
\hline $\begin{array}{l}\text { Main Bibliographical and } \\
\text { Documental references } \\
\text { describing each Policy Area }\end{array}$ & $\begin{array}{l}\text { Teixeira (1997), Parker } \\
\text { (2003), Galvão (2000), } \\
\text { Brasil (2015). }\end{array}$ & $\begin{array}{l}\text { Stuchi, Paula and Paz (2012), } \\
\text { Mestriner (2001), } \\
\text { Brasil (2009), } \\
\text { Sposati (2008, 2009, 2012). }\end{array}$ & $\begin{array}{l}\text { Turino (2009), } \\
\text { Brasil (2013). }\end{array}$ \\
\hline $\begin{array}{l}\text { Primary data - Interviews } \\
\text { conducted between December } \\
2015 \text { and March } 2016\end{array}$ & $\begin{array}{l}\text { Ministry of Health } \\
\text { (Department of STD, } \\
\text { AIDS and Viral Hepatitis, } \\
\text { three managers were } \\
\text { interviewed). }\end{array}$ & $\begin{array}{l}\text { Ministry of Social } \\
\text { Development (Department } \\
\text { of Network of Private Social } \\
\text { assistance SUAS - Unified } \\
\text { System of Social Assistance, } \\
\text { one manager interviewed). }\end{array}$ & $\begin{array}{l}\text { Ministry of Culture } \\
\text { (Secretariat of Citizenship } \\
\text { and Cultural Diversity, one } \\
\text { manager interviewed). }\end{array}$ \\
\hline
\end{tabular}

Source: Elaborated by the authors. 


\subsection{Government-nonprofits relationship models}

The economic perspective that focuses on the market, government, and philanthropic failures for each of the studied policy areas is among the theoretical perspectives that provide an understanding of the government-nonprofits relationship to provide public goods (Hansmann, 1987; Lipsky \& Smith, 1990; Salamon 1995; Young, 2000).

According to Young (2000), there are three models for government-nonprofits relations, the supplementary, complementary and adversarial models. In the supplementary, nonprofits offer new ways to provide services the state fails to offer - usually driving innovation. The more heterogeneous citizen's preferences for public goods are, the more is expected from nonprofits to step in offering such goods, as it happens in the area of culture and arts.

Other studies drawing on a micro-sociological perspective, notably Coston (1998) and Najam (2000), are useful to cover more diverse forms of relationships, highlighting both sector (the main level of analysis of economic approaches) and organizational levels.

Coston (1998) presents a model with eight typologies of government-nonprofit relationships considering institutional pluralism and power asymmetries, ranging from repression to collaboration, as shown in Figure 1.

\section{FIGURE 1 TYPOLOGIES OF GOVERNMENT-NONPROFIT RELATIONSHIPS}

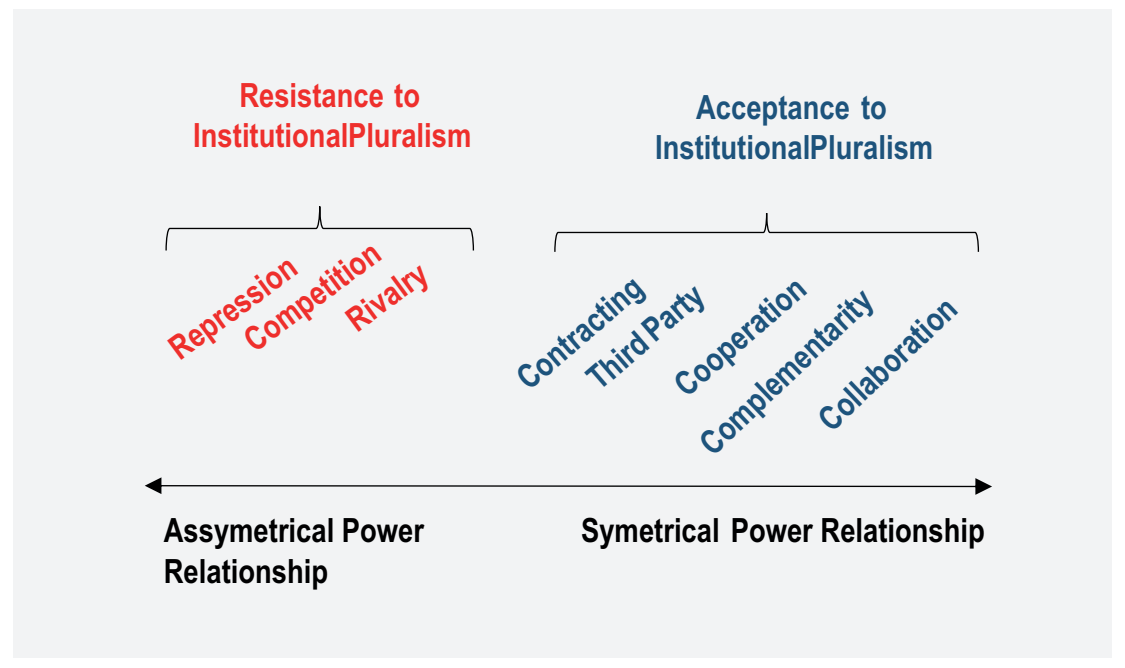

Source: Coston (1998).

Economic arguments for partnerships only become valid in Coston's model for types of relationships that accept institutional pluralism, whereas most formalized types are supported on comparative advantages. The contracting and third party types of relationship are based on formality, while cooperation, complementarity, and collaboration are less formalized types. Degrees of formalization can also appear in a context that rejects institutional pluralism, in the form of policies and regulations that restrict nonprofits activities, or even their existence. 
Coston (1998) and Young (2000) repeatedly mentioned the criteria of efficiency in contracting nonprofits as partners, and that it is important to allow a minimum level of competition among them or even competition between them and the for-profit sector ${ }^{1}$.

Referring to Coston (1998), Najam (2000) defends a simplification on the types proposed, pointing out the difficulty in differentiating some of them, such as cooperation and collaboration. Also, perfect power symmetry is not a prerequisite for cooperation. The cooperative behavior is achieved because none of the actors consider their intentions and actions challenged.

When Najam (2000) refers to cooperation, he acknowledges some different expressions employed in the literature: cooperation, collaboration, co-production, governance, complementarity, among others. They usually refer to practices as diverse as aligned common goals, shared norms, open communication, coordination efforts, comparative advantages, resources sharing, joint action, which are terms also discussed by Coston (1998), Young (2000) and Brinkerhoff (2002).

As a proposal to simplify this classification, using Coston (1998) and Furneaux \& Ryan (2014), we have produced the following scheme:

\section{FIGURE 2 CLASSIFICATION OF GOVERNMENT - NONPROFIT PARTNERSHIPS}

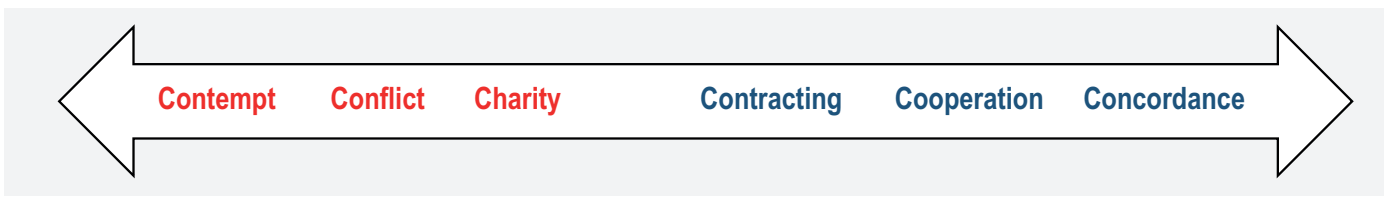

Source: Elaborated by the authors.

Figure 2 summarizes ideal types of partnerships, the initial part of a typology according to Doty and Glick (1994). The types in red on the left may be considered resistant to government interaction and have less potential to produce effective outcomes. On the other hand, the ones on the right, in blue, have greater potential to produce effective outcomes, and except contracting, can be considered more open to participatory interaction. The types of partnership are described below.

In a contempt partnership, the government seeks to restrict the autonomy and influence of nonprofits, through disproportionate controls, regulations limiting the organizations' operation or activities, excessive bureaucratic demands. In this form of relationship, there is little dialogue and a lack of trust between the parties. No common values and goals are identified. There may be persecution of dissident organizations.

In the conflict type, important differences are found in the values and objectives between the parties, making it possible to identify various performance systems, the variance of the professional's profile, and organizational capacities on both sides. Circulation of information is difficult. The government

\footnotetext{
${ }^{1}$ There are several models of Government funding to nonprofits in Brazil: indirect funding through tax exemptions, as well as several forms of contracting and providing grants. Third Party, based on voucher systems, is not a type of relationship found in Brazil.
} 
may find forms of restricting nonprofits activities through regulation, excessive bureaucratic control, but not in a way that prevents the partnerships from occurring. Spaces of dialogue may exist, but they are not effective to support the approximation between government and nonprofits. Nonprofits are more likely to use forms of contentious mobilization to achieve political influence. Open persecutions towards dissidents are unlikely, but funding mechanisms may not be transparent, failing to ensure fair access to resources.

In the Charity type, definitions about partnerships in policy design are low or non-existent. Relationships tend to be sparse or with a low degree of monitoring and control by the government. Participation and interpersonal relationships tend to be more ceremonial.

In the Contracting type, the guidelines and details about partnerships in policy design are highlighted, such as standards, use of shared planning and management tools, and greater detailing of regulation regarding the functioning of partnerships. Relationships under contracting can occur regardless of the alignment of values and goals. However, it requires more developed organizational capacities, both in public bureaucracy and in nonprofits.

In the Cooperation relationships, history of government-nonprofit interaction gains importance. Both formal and informal spaces for participation and dialogue tend to be working. There is some level of sharing of values and goals, ensuring a foundation of trust for relationships. There may be cooperation even in formal contracts using bureaucratic or market logic, but in this type of partnership relational factors and discretion gain prominence, either when it comes to solving potential conflicts, or to improving the model and generating innovations. The relational factors are dependent on the government and nonprofit staff and members profile, as well as the role of the leaders in the construction of the dialogues.

Concordance occurs when the nonprofits involved have great legitimacy and capacity, capable of promoting their differentiation in the eyes of the public agencies with which they relate. There is a strict alignment of values and objectives, allowing for the reduction of control and focus on shared results. The nonprofits tend to be present in services that complement the state to a high degree. The state considers nonprofits as part of its public policies, and seeks integration, with the concern of building joint capacities. This type of relationship needs a high degree of organizational capacities and involvement of leaders and staff in dialogues.

Overall, empirical studies applying the models of partnerships focused on comparisons at the macro level, seeking to classify and position them into a scale showing countries differences or policy areas distinctions (Appe \& Layton, 2016; Bode \& Brandsen, 2014; Buckingham, 2012; Furneaux \& Ryan, 2014; Proulx, Bourque, \& Savard, 2007; Young, 2006).

We note that this set of studies are useful to identify differences and similarities among models and represent good schemes for testing propositions across different contexts. In most studies detailing these models (Brinkerhoff, 2002; Coston, 1998; Najam, 2000) it is possible to observe interorganizational exchanges: information sharing, levels of informal interaction, more or less participation opportunities in decision making, mutual dependence, degree of discretion and autonomy, and different forms of resources sharing, goals alignment.

The main limitation of using typologies or models to capture diversity is that they frequently overlap, making the classification effort an imperfect approximation. The models can be better 
described and detailed to identify and ensure that, even with overlaps, it is possible to deal analytically with the findings. This step, according to Doty and Glick (1994) aims to point out and detail the multiple dimensions that form the ideal types.

Regarding the level of analysis, Najam (2000) pointed out the need to consider both sector features and politics; and the rationality of each institutional/organizational context. Bode and Brandsen (2014) classify studies looking at micro-dynamics of partnerships as a separate subset of studies. Most studies focusing on micro-dynamics are based on case studies, using different variables and categories, making it more difficult to test and compare.

Literature describes models of partnerships without differentiating levels of analysis. We propose to provide greater detail on that, based on two analytical levels: the political-institutional context and the micro-organizational dynamics, and their integration for use in the classification of the partnership models.

Variables linked to the political-institutional context are listed:

1. History of interaction: many studies point to the effects of path dependence. In this sense, a history of greater approximation in the specific context of policy area favors the construction of more collaborative partnerships (Mcloughlin, 2011).

2. Comparative advantages: studies that seek to carry out an economic analysis of the partnerships, analyzing the comparative advantages of the forms of provision and their interactions (Hansmann, 1987; Lipsky \& Smith, 1990, Salamon 1995, Young, 2000). The existence of comparative advantages that promote efficiency, diversification, or increase the quality of services by nonprofits can facilitate collaborations.

3. Government openness: Greater collaboration can be achieved through the existence of institutionalized spaces of participation. The use of other forms of contentious influence by nonprofits in the context of the policy area can either limit collaboration, or, when combined to other strategies, contribute to influence it positively.

4. Regulation: More recent works that seek to update the models of Coston and Najam (AlmogBar \& Zychlinski, 2012; Brown \& Troutt, 2004; Furneaux \& Ryan, 2014; Proulx et al., 2007) have increasingly identified regulatory issues. Regulatory factors aimed at promoting transparency and fair competition should be enabled. Regulatory factors that increase bureaucratic control over nonprofits or that contain ambiguous norms or nonexistent norms making the implementation of partnerships difficult should be disabled.

Variables mediating the inter-organizational relationships are:

5. Nonprofits autonomy: In the question of resource flow and dependence vs. autonomy of nonprofits, many studies have sought to detail and differentiate the forms that affect partnerships, (Johansson, 2003; Mcloughlin; 2011; Mendonça \& Araújo, 2011; Ramanath, 2009). Dependence of funding and autonomy are relational factors and need to be systematically accessed in each context (McLoughlin, 2011) considering the profiles of nonprofits involved.

6. Goal's alignment: Even if actions are complementary, internally if there is no correspondence about the role of the partnership, the objectives tend not to be aligned (Albrecht, 2018). Brinkerhoof (2002) 
refers to mutuality and organizational identity. Mutuality is high when the level of interdependence implies integration with common values collectively defined. Organizational identity refers to the maintenance of autonomy and distinctiveness of a particular organization.

7. Leadership and personal interactions: These are left out of most models (Proulx et al., 2007), but have been identified to have an impact on partnerships (Almog-Bar \& Zychlinski, 2012; Brown \& Troutt, 2004; Shaw 2003).

8. Government Capacity: It refers to administrative procedures and management tools developed or adapted to support partnerships. Some of them are to include the dimension of partnerships in policies planning and evaluation phases, using specific output indicators; providing information systems adapted to deal with specificities of this type of relationships; training public managers. Despite this, the existence of general or sectoral guidelines or policies that can guide and support the provision of services through partnerships with nonprofits is still rare (Brandsen \& Pappe, 2015).

Figure 3 summarizes the analytical model proposed in this study: When after analysis the relationship's factors classification are positioned to the left, the tendency is that the type of partnership is Contempt, Conflict, or Charity. When the factors are positioned to the right, the tendency is that the type of partnership is Contracting, Cooperation, or Concordance, following the range shown in Figure 2. When there is a comparison between relationships, this analytical model allows. Through comparison, it was possible to obtain detail on the differentiates of each case depending on specific contexts.

\section{FIGURE 3 INSTITUTIONAL CONTEXT OF THE POLICY AREA}

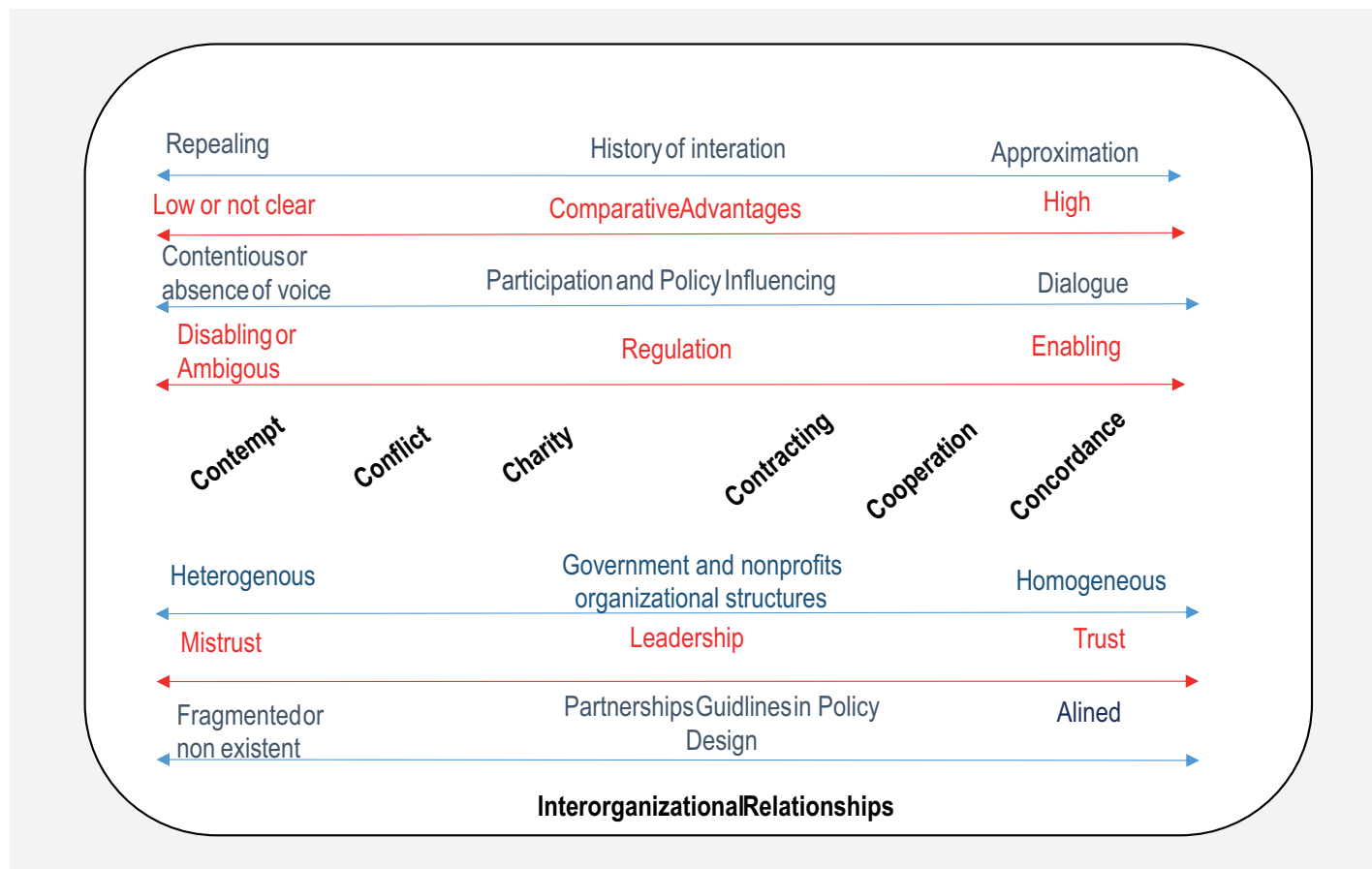

Source: Elaborated by the authors. 


\subsection{Partnership in the context of AIDS, social assistance, and culture}

\subsubsection{AIDS}

Policy on AIDS in Brazil was first drafted in the 1980s, during the country's period of redemocratization. Several social movements resurge demanding rights and for the state to take responsibility for welfare provision (Galvão, 2000).

Different actors took part in these movements: health professionals from the sanitary reform movement, LGBT groups, artists and pro-democracy activists that were diagnosed with HIV and manifested the syndrome during the epidemic (Campos et al., 2012). These mobilizations led to the creation of nonprofits (so-called "AIDS-NGOs,"), and addressed broader demands voiced in healthcare and other social areas, connecting the principles of the Brazilian SUS - Sistema Unico de Saúde (Unified Health System) into the country`s AIDS Program: universality, decentralization, and integration. The international community has acknowledged the Brazilian AIDS Program as a successful example (Parker, 2003; Teixeira, 1997).

Four agreements between the federal government and the World Bank contributed to the process of consolidating and financing this policy. These agreements permitted specific financing of nonprofits through funds raised through international, without involving the public administration procedures directly. This provided a more flexible means to implement projects by removing the need to submit to strict rules and the costs of engaging the state bureaucracy (Campos, 2008).

Within this policy there is a clear definition of roles for the nonprofits and the state: nonprofits promoting prevention and monitor and support the guarantee of rights of people living with HIV and vulnerable groups; and the state providing treatment and specialized health assistance. More recently the focus moved to apply the Rapid HIV tests performed by the nonprofits outside of a lab environment, the so-called "peer testing" (Brasil, 2015).

Before the implementation of the third agreement with the World Bank, the Ministry of Health pressured for more decentralized implementation and integration with SUS (Campos, 2008; UNESCO, 2005). The policy was thus decentralized to state and municipal levels. Planning tools and specific funding mechanisms were created to guarantee the availability of resources to nonprofits on subnational levels.

Nonprofits continued playing a broad role within the AIDS policy. These organizations actively participate in initiatives such as the Commission for Engagement of Social Movements (focused on the accountability of the state-nonprofits relationships); the National Commission on Sexually Transmitted Diseases, AIDS and Viral Hepatitis (focusing on technical aspects related to disease control); and several Technical Chambers within the Department of STD/AIDS (participatory spaces in the structure of the Ministry of Health that engage users, universities, and experts).

\subsubsection{Social assistance}

State-civil society relations in the field of social assistance in Brazil have always been unclear, in a mix of complementarity and subsidiarity, between the duty of the state and private philanthropy. This lack of clarity generates ambiguities and ambivalences in the offer of goods and public services to groups 
at risk and socially vulnerable, such as people with disabilities, children and adolescents, the elderly, and homeless people. (Araújo, 2017; Mestriner, 2001).

Following the provisions of the 1988 Constitution and other regulations regarding social assistance in Brazil, the Sistema Unico de Assistência Social - SUAS (Unified Social Assistance System) was implemented in 2006. The state, therefore, seeks to put in practice a universal social assistance policy where the government has a central role offering guidelines, as well as providing services on its own (Sposati, 2012). The implementation of SUAS with the central role of the state created deep tensions and conflicts with nonprofits previously working on religious/ philanthropic schemes.

SUAS has advanced regarding technical guidelines establishing new bases for the relationship between the state and nonprofits as complementary service providers. The latter became not only service providers, but co-managers by taking part in local social assistance councils and being coresponsible for guaranteeing social rights (Araújo, 2015, BRASIL, PNAS / NOBAS, 2004).

Nonprofits' funding to provide social assistance was made available through indirect funding, such as tax exemptions, and direct funding (grants). Indirect funding required a complex bureaucratic process involving multiple registrations and certification systems that often rely on connections of the nonprofits with legislative houses.

The effective integration of nonprofits in the SUAS is one of the main challenges of state-nonprofits partnerships (Araújo, 2015b, 2017). New parameters and standards regarding the services were introduced, and services offered by nonprofits demanded more integration into the system.

\subsubsection{Cultura Viva}

As the famous singer and songwriter Gilberto Gil took office as Minister of Culture in 2003, a new era began for cultural policies in Brazil. Seeking to revert regional and thematic concentration caused by the previous market-driven policies, the Cultura Viva program was proposed in 2004 to promote cultural organizations that had been excluded from the traditional funding systems (Turino, 2009).

Cultura Viva was designed to strengthen existing cultural practices, promoting the production and circulation of cultural expression of local and community nature. The key structure for implementing this policy are the Pontos de Cultura (Cultural Centers).

The program seeks to support, improve and promote activities that nonprofits already sponsor within their local communities, mainly in remote locations, thus supporting different cultural and artistic expressions throughout all regions of the country. The state recognizes the initiatives of these nonprofits in their communities and offers them the institutional and financial support necessary for the operation, improvement, and expansion of their initiatives. These nonprofits were named Pontos de Cultura.

In many of these organizations, artists or young leaders manage cultural collectives, and the Ponto de Cultura was the first partnership they established with the state. There was no previous expertise on management issues, especially with regards to executing contracts and transferring public resources.

It is important to stress how diverse the organizations that become Ponto de Cultura are, in order to avoid generalizations. However, they do share a common element: They are organizations that operate in networks, as the Cultura Viva program is designed for network activities. Thus, the Pontos de Cultura influence one another, including those that do not receive funds directly from the government program (Medeiros et al., 2015). 
Despite its innovative proposal in more horizontal policy implementation, the policy design did not create adequate regulatory and management tools to deal with specific and diverse profiles of cultural nonprofits, such as training, guidelines, monitoring systems. As these organizations are submitted to the bureaucratic rules of government, they face challenges and changes in the way they act (Medeiros, 2013).

Several participating organizations mobilized and pressured for changing procedures, being successful in proposing a bill to the Congress, which passed as Law 13018/2014. However, the law still lacks some details, definitions, and regulations in the state`s bureaucracy in order to be properly implemented.

\subsection{Analysis of the relationship models in the policy areas of AIDS, social assistance and culture}

The analytical model explained in Figures 2 and 3 were used to summarize the three cases in Box 2 below. We used the data described in Box 1 of the methodology.

We have made an effort to understand what leads a partnership to a more collaborative or more conflicting spectrum, as shown in Figure 2. To do so, we delimit two types of factors, one related to the political-institutional context and the other to micro-organizational relations, as shown in Figure 3. The visual comparison of the three cases in Box 2 is facilitated, with red cells representing more conflictive models and blue cells the more collaborative ones. We used this systematization to discuss the cases separately and to propose classifications for each partnership's models found.

COMPARISON OF MODELS OF PARTNERSHIP

\begin{tabular}{|c|c|c|c|}
\hline & AIDS & Social assistance & Cultura Viva \\
\hline \multicolumn{4}{|c|}{ Political-Institutional Context } \\
\hline $\begin{array}{l}\text { 1-History of } \\
\text { Interaction }\end{array}$ & $\begin{array}{l}\text { Nonprofits play a central role } \\
\text { in creating and designing } \\
\text { the policy (Teixeira, 1997; } \\
\text { Parker, 2003; Galvão, 2000). }\end{array}$ & $\begin{array}{l}\text { Nonprofits as major service } \\
\text { providers, even with recent } \\
\text { changes and the expansion of } \\
\text { public provision and the increase of } \\
\text { competition (Araújo, 2015a, 2015b, } \\
\text { 2017). }\end{array}$ & $\begin{array}{l}\text { The state having a central role in } \\
\text { creating and enabling cultural goods, } \\
\text { along with the market (Medeiros, } \\
\text { 2013; Medeiros et al., 2015). }\end{array}$ \\
\hline $\begin{array}{l}\text { 2-Comparative } \\
\text { Advantages }\end{array}$ & $\begin{array}{l}\text { Complementarity } \\
\text { (Campos \& Mendonça, } \\
\text { 2010; Campos et al., 2012). }\end{array}$ & $\begin{array}{l}\text { Model of competition for public } \\
\text { provisioning and nonprofits (Araújo, } \\
\text { 2015a, 2015b, 2017). }\end{array}$ & $\begin{array}{l}\text { Well defined supplementary to } \\
\text { state. State foment society's cultural } \\
\text { initiatives not present in mainstream } \\
\text { cultural policies (Turino, 2009; } \\
\text { Medeiros, 2013; Medeiros et al., } \\
\text { 2015). }\end{array}$ \\
\hline
\end{tabular}




\begin{tabular}{|c|c|c|c|}
\hline & AIDS & Social assistance & Cultura Viva \\
\hline $\begin{array}{l}\text { 3- Government } \\
\text { Openness }\end{array}$ & $\begin{array}{l}\text { Institutionalized spaces of } \\
\text { participation at the Ministry } \\
\text { of Health combined by } \\
\text { other forms of contentious } \\
\text { policy by nonprofits (primary } \\
\text { data- Interview at Minister of } \\
\text { Health). }\end{array}$ & $\begin{array}{l}\text { National Social Assistance Council } \\
\text { (CNAS) provides an institutionalized } \\
\text { space for participation of } \\
\text { nonprofits, user and service } \\
\text { workers, the former having more } \\
\text { influence. Nonprofits have great } \\
\text { influence through strong lobbies } \\
\text { at the Congress (Araújo, 2015a, } \\
\text { 2017). }\end{array}$ & $\begin{array}{l}\text { Informal openness, but no } \\
\text { institutionalized spaces of participation } \\
\text { (Medeiros, 2013; Medeiros et al., } \\
\text { 2015). }\end{array}$ \\
\hline 4- Regulation & $\begin{array}{l}\text { Complete, clear and } \\
\text { well internalized into } \\
\text { implementation system } \\
\text { (Mendonça, 2018). }\end{array}$ & $\begin{array}{l}\text { Detailed and considered confusing } \\
\text { by nonprofits. Imposes bureaucratic } \\
\text { burdens (Mendonça, 2018; Araújo, } \\
\text { 2015a, 2017). }\end{array}$ & $\begin{array}{l}\text { Ambiguous and incomplete regulation } \\
\text { might compromise decentralization } \\
\text { and operationalization (Medeiros et al., } \\
\text { 2015; Mendonça, 2018). }\end{array}$ \\
\hline \multicolumn{4}{|c|}{ Micro-Organizational Dynamics } \\
\hline $\begin{array}{l}\text { 5- Nonprofits } \\
\text { Autonomy }\end{array}$ & $\begin{array}{l}\text { Politically engaged and well- } \\
\text { structured organizations with } \\
\text { high technical capacities } \\
\text { developed. Presence of } \\
\text { multiple sources of funding. }\end{array}$ & $\begin{array}{l}\text { Nonprofits largely funded by } \\
\text { the state. Only a few more } \\
\text { professionalized able to deal with } \\
\text { dependence. }\end{array}$ & $\begin{array}{l}\text { Predominance of small organizations } \\
\text { some with informal structures. Even the } \\
\text { short period of implementation impacts } \\
\text { on weakening nonprofits autonomy } \\
\text { (Medeiros et al., 2015). }\end{array}$ \\
\hline $\begin{array}{l}\text { 6- Goal's } \\
\text { Alignment }\end{array}$ & High alignment of goals. & $\begin{array}{l}\text { Low alignment. State's logic toward } \\
\text { broad policy goals and nonprofits' } \\
\text { logic predominantly focused on } \\
\text { philanthropy, charity, and religious } \\
\text { values (Sposati, 2008, 2009, } \\
\text { 2012). }\end{array}$ & $\begin{array}{l}\text { Weak capacity for implementation } \\
\text { at the central level. Difficult } \\
\text { decentralization- no differentiation of } \\
\text { responsibilities among subnational } \\
\text { levels } \\
\text { (Medeiros, 2013; Medeiros, Alves \& } \\
\text { Farah, 2015). }\end{array}$ \\
\hline 7- Leadership & $\begin{array}{l}\text { Nonprofit Activists and } \\
\text { Health professional with } \\
\text { strong ties (Campos et al., } \\
\text { 2012). }\end{array}$ & $\begin{array}{l}\text { Strong presence of politicians } \\
\text { representing interests of nonprofits } \\
\text { (primary data- Interview at Minister } \\
\text { of Social Development). }\end{array}$ & $\begin{array}{l}\text { Supporting leader of the Cultura Viva } \\
\text { Program at one unit of the Minister } \\
\text { of Culture (primary data- Interview at } \\
\text { Minister of Culture; Medeiros, 2013) }\end{array}$ \\
\hline $\begin{array}{l}\text { 8- Government } \\
\text { Capacity }\end{array}$ & $\begin{array}{l}\text { Partnerships considered } \\
\text { at planning and evaluation } \\
\text { instruments (Campos, 2008; } \\
\text { UNESCO, 2005). }\end{array}$ & $\begin{array}{l}\text { Difficult application of service } \\
\text { standards and other management } \\
\text { instruments created to be part of } \\
\text { the SUAS (Araújo, 2015a). }\end{array}$ & $\begin{array}{l}\text { Proposition of innovative network } \\
\text { structure, still difficult to operationalize } \\
\text { (Medeiros, 2013; Medeiros et al., } \\
\text { 2015). }\end{array}$ \\
\hline
\end{tabular}

Source: Elaborated by the authors.

In the AIDS case, there is a convergence of shared objectives and strategies between nonprofits and the state, which is present since the mobilization to drafting of the agenda during the late 1980s. Roles are clearly defined: the State must provide healthcare and treatment for HIV-infected people, while nonprofits perform prevention efforts and defend patients' rights. Among the three cases studied, this one shows more comparative advantages, when AIDS nonprofits perform tasks that are not easily done by the state. 
There are many dialogues and participatory spaces in different areas at the Ministry of Health, with several means of consulting and producing data and shared knowledge. Professionals in the public sector in the health area have more involvement with social movements, as this area is also one that presents administrative structures and management capacities are more developed among the areas compared. The AIDS program, in particular, presents a shared policy design, including partnerships as central in its formulation. It is possible to acknowledge planning schemes, technical exchanges, the establishment of goals, and indicators regarding partnerships.

Nonprofits on the field accessed other types of funding, not only state funds, but particularly those from the cooperation agreement with the World Bank and other nonprofit international donors. These partners also invested heavily in their capacity bulling. Nonprofits working on AIDS manage to keep their autonomy and influence in the policy, developing a more organic relationship with the state, including a constant exchange of professionals between the government and the organizations, active engagement in different instances of the Ministry/Department of AIDS. This combination of complementarity, dialogue history of approximation and smooth coordination can position the partnership in the area as a cooperation model.

In the case of social assistance, recent changes on the policy have added levels of tensions in the relations. The state provision has been strengthened, causing competition, in a model that could previously be characterized as charity. Changes also implied conflicts over strategies of work. Nonprofits operated under more paternalistic forms, while the state operated in a way to safeguard people's rights within a universalistic framework. Tensions also aroused when stricter rules to receive indirect public funding were in place (mainly through tax deduction and exemptions).

The Ministry of Social Development has experienced crescent professionalization in the period analyzed. In this case, the impact on the partnerships was negative, with the nonprofits taking the standards of services and other guidelines as pressures for their functioning. This is, therefore, a model of conflict and contracting characteristics.

As for culture, the case observed was a new program with unique features not ever seen in cultural policies in Brazil, with many innovations not only in goals but also on strategies such as the promotion of networks and more horizontal forms of providing services. The new program benefited from the leadership of the minister Gilberto Gil and its technical staff. The leadership was also important in building dialogues and alignment with cultural organizations. There is an alignment of goals, as the state seeks to recognize and promote local cultural initiatives, their singularities, in a supplementary design of provision, meaning the state was not able to produce services without nonprofits.

However, the Ministry of Culture did not have the resources to put all the goals into practice. The policy still needs to improve its regulation, in order to allow the Minister of Culture to operate with less bureaucracy to control processes. Despite the organization of events and the promotion of networks, nonprofits do not have formal participation spaces to influence policy, as it is possible to observe in other policy areas. The nonprofits influence in a less formalized manner, creating coalitions, but in an incipient form, due to the heterogeneity of the organizations in the field.

Nonprofits initially welcomed Cultura Viva enthusiastically. However, the attempt of the government to support the work of nonprofits resulted in co-optation instead, as these organizations submit to bureaucratic demands to such an extent that their other activities are compromised. Thus, this showed mixed aspects of contracting and conflict models. 


\section{CLOSING REMARKS}

The literature on partnerships focuses on the great diversity of nonprofits and models of partnership with the state for providing services (Coston, 1998; Brinkerhoof, 2002; Najam, 2000; Young, 2000, 2006). Most empirical studies using this framework tend to make efforts to categorize partnerships, usually comparing countries or policy areas on a macro level (Appe \& Layton, 2016; Bode \& Brandsen, 2014; Buckingham, 2012; Furneaux \& Ryan, 2014; Proulx et al., 2007; Young, 2006).

This study sought to contribute to the use of these models to understand differences among policy areas. In doing so, it introduced field level variables and organizational variables to better differentiate models and to identify overlaps.

Through the use of these models we seek to understand the differences between the partnerships in the different public policies. In doing so, we introduce field-level variables and organizational variables to better differentiate models and identify overlaps.

We compare partnerships in the areas of AIDS, social assistance and culture. Differences between them have helped us test more relational variables to produce analyzes using the models.

Approaches that highlight field level and organizational features are important to understanding why one model is implemented instead of others. Different models could be identified. For the AIDS policy, the cooperation model prevails. For social assistance, we could identify a changing environment combining conflict and contracting characteristics, which evolved from a previous charity format. A conflict model prevails and grows as policy changes are implemented. For culture, the prevailing model is ambiguous and presents contracting and conflict features.

Therefore, these models are never pure, and we cannot say beforehand that cooperation is the ideal form of partnership. This would be a primary suggestion for future research. Does cooperation lead to higher efficiency, better quality services, efficacy and integration with the policy? Moreover, which of the elements that enable the partnership lead to more cooperative or confrontational models? This is the agenda introduced for future research.

In this study, we sought to complement the analysis of models of partnership (Najam, 2000; Young, 2000 ) with other elements, such as nonprofits profile and their professionals, types of funding, spaces of engagement, and elements that have been analyzed in other studies (Buckingham, 2012; Furneaux \& Ryan, 2014; Proulx et al., 2007).

We believe that future research focusing on this agenda can combine qualitative and quantitative approaches with surveys about specific elements of the partnerships and features of nonprofits. They can also test variation in models with the same policy areas distributed to different local implementation context and governmental level.

Regarding policy implications, the outcomes of this research support the recommendation of efforts to advance a state agenda on partnerships that can combine general guidelines with specificities of policy areas. Partnerships should be seen as instruments of public policy, continuously remembering that public action goes well beyond the state. 


\section{REFERENCES}

Albrecht, K. (2018). Institutional logics and accountability: Advancing an integrated framework in nonprofit - public partnerships. Journal of Public and Nonprofit Affairs, 4(3), 284-305. Retrieved from https://doi.org/10.20899/jpna.4.3.284-305.

Almog-Bar, M., \& Zychlinski, E. (2012). A Façade of Collaboration: Relationships between philanthropic foundations and the government in social policymaking in Israel. Public Management Review, 14(6), 795-814. Retrieved from https://doi.org/10.1080/14 719037.2011.642625.

Alves, M. A., \& Koga, N. M. (2006). Brazilian nonprofit organizations and the new legal framework: an institutional perspective. $B A R$ - Brazilian Administration Review, 3(2), 68-83. Retrieved from https://dx.doi.org/10.1590/S180776922006000200006.

Appe, S., \& Layton, M. (2015). Government and the Nonprofit Sector in Latin America. Nonprofit Policy Forum, 7(2), 117-135. Retrieved from http://doi. org/10.1515/npf-2014-0028.

Araújo, E. T. (2015a). Documento técnico contendo levantamento e análise das orientações técnicas, documentação e normativas do CNEAS; bem como padronização de conceitos e conteúdos inerentes aos serviços programas, projetos e benefícios socioassistenciais. Projeto BRA12/006 MDS, Pnud. Brasília, DF: MDS.

Araújo, E. T. (2015b). Documento técnico contendo proposta de Manual de Orientação aos Gestores da Política de Assistência Social no que concerne ao Cadastro Nacional de Entidades de Assistência Social (CNEAS). Projeto BRA12/006 MDS, Pnud. Brasília, DF: MDS.

Araújo, E. T. (2015c). Avaliação do processo de implementação dos Centros-dia de Referência para a Pessoa com Deficiência e suas Famílias, no âmbito do Plano Viver Sem Limite, na Região Nordeste. Relatório Final de Pesquisa. Projeto apoiado pela chamada pública MCTI-CNPq/ MDS-SAGI No 24/2013 - DESENVOLVIMENTO SOCIAL, no TEMA 1: Assistência Social - 1.6 A Implementação do Plano Viver Sem Limites. Brasília, DF: MDS.
Araújo, E. T. (2017). Gestão Social e a Política Pública de Assistência Social. Curso gestão social. In J. M. Oliveira Neto, \& J. T. Silva Jr. (Org). Fortaleza, CE: Fundação Demócrito Rocha/UANE/BID/STDS-Ce. (Curso em 12 Fascículos).

Bode, I., \& Brandsen, T. (2014). State-third Sector Partnerships: A short overview of key issues in the debate. Public Management Review, 16(8), 10551066. Retrieved from https://doi.org/10.1080/1471 9037.2014.957344.

Boullosa, R. F. (2013). O SUAS e a Proteção Social Especial para a Pessoa com Deficiência: um caso de inovação em políticas públicas? In Anais do 180 Congreso CLAD sobre la Reforma del Estado y de la Administración Pública, Montevideo, Uruguay.

Brandsen, T. \& Pape, U. (2015). The Netherlands: The Paradox of Government-Nonprofit Partnerships. Voluntas: International Journal of Voluntary and Nonprofit Organizations, 26(6), 2267-2282. Retrieved from https://doi.org/10.1007/s1 1266-015-9646-3.

Brasil (2004). Política Nacional de Assistência Social (PNAS), Resolução CNAS- no 145/2004. CNAS: Brasília, DF. Retrieved from https://www.mds.gov. br/webarquivos/publicacao/assistencia_social/ Normativas/PNAS2004.pdf.

Brasil (2009). Tipificação Nacional dos Serviços Socioassistenciais. Texto da Resolução no 109, de 11 de novembro de 2009. Brasília, DF. Retrieved from https://www.mds.gov.br/webarquivos/publicacao/ assistencia_social/Normativas/tipificacao.pdf.

Brasil. Ministério da Cultura (2013). Programa Arte Cultura e Cidadania - Cultura Viva. Brasília, DF. Retrieved from http://www.cultura.gov.br/ culturaviva/cultura-viva/.

Brasil. Ministério da Saúde (2015). Projeto Brasil Aids-SUS. P3540/LN7901-BR. Ministério da Saúde Secretaria de Vigilância em Saúde Departamento de DST, Aids e Hepatites Virais: Brasília, DF.

Brinkerhoff, J. (2002). Government-nonprofit partnership: a defining framework. Public Administration and Development, 22(1), 19-30.

Brown, L. K., \& Troutt, E. (2004). Funding Relations between Nonprofits and Government: A Positive Example. Nonprofit and Voluntary Sector Quarterly, 33(1), 5-27. Retrieved from https://doi. org/10.1177/0899764003260601. 
Buckingham, H. (2012). Capturing Diversity: A Typology of Third Sector Organizations' Responses to Contracting Based on Empirical Evidence from Homelessness Services. Journal of Social Policy, 41(3), 569-589. Retrieved from https://doi. org/10.1017/S0047279412000086.

Campos, L. C. M. (2008). ONGs/AIDS: acesso a fundos públicos e sustentabilidade de ações. $R A E$ Revista de Administração de Empresas, 48(3), 81-93. Retrieved from http://dx.doi.org/10.1590/S003475902008000300008 .

Campos, L. C. M., \& Mendonça, P. (2010). Provisão compartilhada de Serviços Públicos: configuração e desafios a partir da análise da Política Nacional de Combate ao HIV/Aids. Revista Economia \& Gestão, 10(23), 100-117.

Campos, L. C. M., Mendonça, P. M., \& Alves, M. A. (2012). From dot.org to dot.gov: Professional Crossings in the Brazilian National Policy on HIV/ AIDS. Voluntas: International Journal of Voluntary and Nonprofit Organizations, 23(1), 236-256. Retrieved from https://doi.org/10.1007/s11266011-9195-3.

Coston, J. M. (1998). A Model and Typology of Government - NGO Relationship. Nonprofit and Voluntary Sector Quarterly, 27(3), 358-382. Retrieved from http://dx.doi.org/10.1177/0899764098273006.

Doty, D., \& Glick, W. (1994). Typologies as a Unique Form of Theory Building: Toward Improved Understanding and Modeling. The Academy of Management Review, 19(2), 230-251. Retrieved from http://www.jstor.org/stable/258704.

Eisenhardt, K. (1989). Building Theories from Case Study Research. The Academy of Management Review, 14(4), 532-550. Retrieved from http://www. jstor.org/stable/258557.

Furneaux, C., \& Ryan, N. (2014). Modelling NPO - Government Relations: Australian case studies. Public Management Review, 16(8), 1113-1140, Retrieved from https://doi.org/10.1080/14719037. 2014.895030

Galvão, J. (2000). AIDS no Brasil: a agenda de construção de uma epidemia. Rio de Janeiro: ABIA; São Paulo, SP: Ed. 34.

Hansmann, H. (1987). Economic theories of nonprofit organization. In W. W. Powell (Ed.).
The Nonprofit Sector: A Research Handbook. New Harlem, NY: Yale University Press.

Johansson, S. (2003). Independent Movement or Government Subcontractor? - Strategic Responses of Voluntary Organizations to Institutional Processes. Financial Accountability \& Management, 19(3), 209224. Retrieved from https://doi.org/10.1111/14680408.00171.

Lacoumes, P., \& Le Galés, P. (2012). Sociologia da Ação Pública. Tradução e estudo introdutório: George Sarmento, Maceió, AL: EDUFAL.

Lipsky, M., \& Smith, S. (1989). Nonprofit Organizations, Government, and the Welfare State. Political Science Quarterly, 104(4), 625-648. Retrieved from http://www.jstor.org/stable/2151102.

Lopez, F. G., \& Abreu, R. (2014). A Participação das ONGs nas Políticas Públicas: o ponto de vista dos gestores federais. IPEA, Textos para Discussão 1949. Brasília, DF: IPEA. Retrieved from http:// www.ipea.gov.br/portal/index.php?option $=\mathrm{com}_{-}$ content\&view $=$ article\&id $=22088$

Lopez, F., Lopes, L. F., Souto, B. \& Sant'Ana, D. (2014). A interação entre organizações da sociedade civil e governo federal: Colaboração nas políticas públicas e aperfeiçoamentos regulatórios possíveis. Brasil em desenvolvimento - Estado planejamento e políticas públicas. v. 2. Brasília, DF: Ipea. Retrieved from http://www.secretariageral.gov.br/atuacao/ mrosc/artigos/brasil-em-desenvolvimento-2014ipea.pdf.

Mcloughlin, C. (2011). Factors Affecting State - Non governmental organizations relations in service provision: key themes from the literature. Public Administration and Development, 31(4), 240-251. Retrieved from https://doi.org/10.1002/pad.611.

Medeiros, A. K., Alves, M. A., \& Farah, M. F. S. (2015). Programa Cultura Viva e o campo organizacional da cultura: análise de políticas públicas pela perspectiva institucionalista. Revista de Administração Pública, 49(5), 1215-1235. Retrieved from https://dx.doi. org/10.1590/0034-7612130337.

Medeiros, A. K. (2013). Políticas públicas e organizações culturais: o caso do programa Cultura Viva (Master Thesis). Escola de Administração de Empresas de São Paulo, Fundação Getulio Vargas, 
São Paulo. Retrieved from http://hdl.handle. net/10438/10653.

Mendonça, P. M., \& Araujo, E. T. (2011). Sustentabilidade organizacional em ONGs: os casos do Gapa-BA e do Grupo Brasil a partir das contribuições da Teoria da Dependência de Recursos. Revista Gestão \& Planejamento, 12(1), 112-132. Retrieved from https://revistas.unifacs.br/ index.php/rgb/article/view/1120.

Mendonça, P. M. E. (2018). Paradigms of Public Management and the Historical Evolution of State CSO Partnerships: A Comparison of AIDS, Social Assistance, and Cultural Policy. In A. B. Savignon, L. Gnan, A. Hinna, \& F. Monteduro (Org.). Studies in Public and Non-Profit Governance. (Vol. 6, 1. ed., pp. 111-130) Bingley: Emerald Publishing Limited.

Mestriner, M. L. (2001). O Estado entre a filantropia e a assistência social. São Paulo: Cortez.

Najam, A. (2000). The Four C's of Government Third Sector-Government Relations. Nonprofit Management and Leadership, 10(4), 375-396. Retrieved from https://doi.org/10.1002/nml.10403.

Parker, R. (2003). Construindo os alicerces para a resposta ao HIV/AIDS no Brasil: o desenvolvimento de políticas sobre o HIV/AIDS, 1982-1996. Divulgação em Saúde para Debate. Londrina, PR: Centro Brasileiro de Estudos da Saúde.

Peci, A., Figale, J. \& Sobral, F. (2011). The Invasion of Manufactured Civil Society: government-nonprofit partnerships in a Brazilian state. Public Admin. Dev., 31(5), 377-389. Retrieved from https://doi. org/10.1002/pad.603.

Proulx, J., Bourque, D., \& Savard, S. (2007). The Government-Third Sector Interface in Québec. Voluntas: International Journal of Voluntary and Nonprofit Organizations, 18(3), 293-307. Retrieved from https://doi.org/10.1007/s11266-007-9045-5.

Ramanath, R. (2007). Limits to Institutional Isomorphism: Examining Internal Processes in NGO - Government Interactions. Nonprofit and Voluntary Sector Quarterly, 38(1), 51-76. Retrieved from https://doi.org/10.1177/0899764008315181.

Resende, G. A., \& Teodósio, A. S. (2014). Democratização de políticas sociais no Brasil: venturas e desventuras das organizações da sociedade civil. Civitas: Revista de Ciências Sociais, 14(1), 177-192. Retrieved from http://dx.doi. org/10.15448/1984-7289.2014.1.10689.

Salamon, L. M. (1995). Partners in Public Service: Government - Nonprofit Relations in the Modern Welfare State. Baltimore, US: The Johns Hopkins University Press.

Salinas, N. S. (2013). Modelos de controle das parcerias entre Estado e entidades do terceiro setor e desenho institucional das políticas públicas. Revista de Direito do Terceiro Setor, 7(14), 9-28.

Shaw, M. M. (2003). Successful collaboration between the nonprofit and public sectors. Nonprofit Management and Leadership, 14(1), 107-120. Retrieved from https://doi.org/10.1002/nml.24.

Sposati, A. (2008). Territorialização e desafios à gestão pública inclusiva: o caso da assistência social no Brasil. In Anais do 130 Congreso Internacional del CLAD sobre la Reforma del Estado $y$ de la Administración Pública, Buenos Aires, Argentina.

Sposati, A. (2009). Modelo brasileiro de proteção social não contributiva: concepções fundantes. In Ministério do Desenvolvimento Social e Combate à Fome (MDS), \& Organização das Nações Unidas para a Educação, a Ciência e a Cultura (UNESCO). Concepção e gestão da proteção social não contributiva no Brasil. Brasília, DF: author.

Sposati, A. (2012). Desafios do sistema de proteção social. In C. G. Stuchi, R. F. S. Paula, \& R. D. O. $\mathrm{Paz}$ (Org.) Assistência Social e Filantropia: cenários contemporâneos. São Paulo, SP: Veras.

Stake, R. E. (1995). The art of case study research. Thousand Oaks, CA: Sage.

Stuchi, C. G; Paula, R. F. S.; Paz, R. D. O. (2012). Assistência Social e Filantropia: cenários contemporâneos. São Paulo, SP: Veras.

Teixeira, P. T. (1997). Políticas Públicas em Aids in Políticas, instituições e Aids: enfrentando a epidemia no Brasil. Rio de Janeiro, RJ: ABIA.

Turino, C. (2009). Ponto de cultura: o Brasil de baixo para cima. (2. ed.) São Paulo, SP: Anita Garibaldi. 
UNESCO. (2005). Response to Aids challenges in Brazil: limits and possibilities. Brasilia, DF: author.

Young, D. R. (2000). Alternative models of government-nonprofit sector relations: theoretical and international perspectives. Nonprofit and Voluntary Sector Quarterly, 29(1), 149-172. Retrieved from https://journals.sagepub.com/doi/ abs/10.1177/0899764000291009.

\section{Patrícia Maria Emerenciano de Mendonça}

https://orcid.org/0000-0002-5675-4261

$\mathrm{PhD}$ in Public Administration and Government from Getulio Vargas Foundation School of Business Administration in São Paulo (FGV EAESP); Coordinator of the Master Program in Public Policy Management at School of Arts Sciences and Humanities of University of São Paulo (EACH-USP). E-mail: pmendonca@usp.br

\section{Anny Karine de Medeiros}

https://orcid.org/0000-0002-9208-5720

Master and Doctoral Student in Public Administration and Government from Getulio Vargas Foundation School of Business Administration in São Paulo (FGV EAESP). E-mail: annykmedeiros@gmail.com

\section{Edgilson Tavares de Araújo}

https://orcid.org/0000-0002-2145-8796

$\mathrm{PhD}$ in Social Work from the Pontifical Catholic University of São Paulo (PUC-SP); Postdoctoral student at University of Brasília (UnB) in the Postgraduate Program in Development, Society and International Cooperation of the Center for Advanced Multidisciplinary Studies; Professor at Federal University of Bahia (UFBA); Productivity Fellow in Technological Development and Innovative Extension of the National Council for Scientific and Technological Development (CNPq). E-mail: edgilson@gmail.com 